\title{
REVIEW
}

\section{On the diets of calanoid copepods}

\author{
G. S. Kleppel \\ Nova University Oceanographic Center, 8000 North Ocean Drive, Dania, Florida 33004, USA
}

\begin{abstract}
A review of the literature (ca 1900 to 1992) on copepod feeding indicates that combinations of stochastic and deterministic processes result in behaviors, or feeding strategies, that optimize nutritional gain from the food environment, and further, that strategies change in response to environmental variability. Because the diet is the product of a feeding strategy, one may gain insight into the ways in which copepods respond to their food environments by measuring their diets. Investigations of the links between copepod feeding and production suggest that dietary diversity is often a key to the procurement of a nutritionally complete ration, and the optimization of secondary production within constraints dictated by the physical environment. The ability to eat different kinds of foods (omnivory) and the tendency to include a variety of foods in the daily ration may enhance the probability of obtaining a nutritionally complete ration in variable, nutritionally dilute, food environments. The notion that the relationship between feeding and production in copepods is driven by dietary diversity is derived in part from a recent recognition of the diversity of microplanktonic organisms that potentially or actually contribute to the diet. Further, the concept is consistent with current trophic dynamic models in which food webs are envisioned as complex interwoven systems rather than short, simple chains.
\end{abstract}

\section{INTRODUCTION}

This paper is concerned with the diets of small calanoid copepods, which historically have been considered predominantly herbivorous or omnivorous. The term 'diet' is defined here as the amount of each kind of food that an animal ingests over some period of time. This definition emphasizes the links between the quantitative aspects of feeding, viz. the ingestion rate, and the qualities of the particles ingested.

Attempts to measure the copepod diet and to understand its significance in terms of secondary production have been prominent themes in the literature for many decades (cf. Marshall \& Orr 1955, Ryther 1969, MoreyGaines 1980, Lasker 1988, Kleppel et al. 1991). It has become apparent that both the kinds and quantities of food in the diet affect copepod production (Durbin et al. 1983, Roman 1984) and, ultimately, production at higher trophic levels (Hardy 1924, Ryther 1969, Smith \& Eppley 1982). It has also become evident that, in addition to chance encounters with food particles, there is a cognitive component to feeding (Donaghay
\& Small 1979, Alcaraz et al. 1980, Strickler 1982). Copepods can actively search for, capture and choose to ingest or reject potential food particles.

If feeding can be selective, then the role that copepods play in the ecosystem is, in part, a function of the strategies they use to obtain their diets. The feeding strategy represents the copepod's response to a food environment composed of many kinds of particles, which is acted upon by an array of fluid dynamic processes (Legendre \& Demers 1984, Haury \& Pieper 1988, Rothschild 1988, Rothschild \& Osborne 1988). Understanding the relationship between feeding and production depends upon one's ability to measure that environment and to understand some of the mechanisms that underlie the copepod's response to it.

Recent reviews (e.g. Paffenhöfer 1988) have emphasized the relationship between copepod feeding, anatomical structure and behavior. This paper considers a somewhat different perspective, the relationship between the food environment, the diet and production. I will trace the evolution of current thinking on copepod feeding and, in doing so, will describe the changing 
focus of feeding theory from carbon-based models to nutritional models which consider the consequences of the copepod's responses to both the quantitative and qualitative attributes of the food environment.

\section{FEEDING STRATEGIES - ADAPTIVE RESPONSES TO ENVIRONMENTAL VARIABILITY}

There are well over 1000 extant species of marine and estuarine calanoid copepods (Raymont 1983). The feeding activities of relatively few of these have been studied. Most of the existing measurements have been made in the dark, at experimentally specified temperatures and in homogeneously distributed, unialgal food environments with cultured copepods when possible (e.g. Mullin \& Brooks 1967, Paffenhöfer 1970, 1971, Harris \& Paffenhöfer 1976, Paffenhöfer \& Harris 1976). Among the goals of these studies has been to determine, in a systematic way, the effect of varying physical environment, food composition and food concentration on feeding rates [see major summaries or edited volumes by Parsons et al. (1977), Kerfoot (1980) Raymont (1983)]. It has been observed that: (1) feeding activity is influenced predictably by temperature (Heinle 1969, Kiørboe et al. 1982, 1985); (2) within limits imposed by the physical environment, the ingestion rate varies rectilinearly with particle concentration, the initial slope of the relationship being affected by particle size or biomass (Mullin 1963, Parsons et al. 1967, Hargrave \& Geen 1970, Frost 1972, 1977, Nival \& Nival 1973, 1976, Mullin et al. 1975, Reeve \& Walter 1977, Bartram 1980, Poulet \& Marsot 1980, but also see Mayzaud \& Poulet 1978, Huntley 1981); and (3) the rate at which water is processed to remove particles (i.e. the clearance or 'filtration' rate) is governed by the sensory-motor capabilities of the copepod species and by specific attributes (e.g. size distribution) of the particles in the food environment (Paffenhöfer 1971, 1988, Frost 1972). Paffenhöfer (1988) described the variety of density-dependent clearance patterns exhibited by calanoid copepods and showed how different responses arise from the anatomical and physiological adaptations of different species.

There has, over the past 2 decades, been a continuous interest in field-validation of these laboratory observations by the use of in situ measurements (Mackas \& Bohrer 1976, Boyd et al. 1980, Dagg \& Grill 1980, Kiørboe et al. 1982, Dagg \& Wyman 1983, Schnack \& Elbrächter 1983, Turner 1984b, Kleppel 1988 ) and incubation experiments with natural particle samples (Poulet 1973, 1978, Poulet \& Chanut 1975. Roman \& Rublee 1981, Gifford \& Dagg 1988, White \& Roman 1991, 1992, Kleppel 1992). Although field methodologies are imperfect and sometimes controversial (Harbison \& McAlister 1980, Conover et al. 1986, Lopez et al. 1988, Penry \& Frost 1990, 1991, Gieskes et al. 1991, Head \& Harris 1992, but also see Kiørboe \& Tiselius 1987, Dam \& Peterson 1988, Durbin et al. 1990), they have helped us to better appreciate that the complex food environments to which copepods are exposed in nature are reflected in the diets (Kleppel \& Pieper 1984, Turner 1984a, b, c, 1985, 1987, Hopkins 1985, Kleppel et al. 1988, 1991) and, therefore, the feeding strategies (Price 1988) of these animals

The question of whether copepods feed selectively, by evaluating the suitability of individual particles as food, or non-selectively, by randomly searching the environment with feeding currents and ingesting every particle that is captured, has been debated since at least the first half of the century (Easterly 1916. Cannon 1928, Lowndes 1935, Harvey 1937). The latter model was favored until the mid-1970s (Anraku \& Omori 1963, Wilson 1973). Filtration was thought to be the principle food-catching mechanism (Anraku \& Omori 1963, Wilson 1973), though raptorial processes were also reported (Richman \& Rogers 1969). Boyd (1976) proposed that the filtering apparati, the second maxillae, generally behave as 'leaky sieves', retaining particles larger than the distance between setae on the endites (the intersetal distance) most efficiently.

Increasingly, however, observers (e.g. Poulet \& Chanut 1975) reported that, contrary to filtration theory (such as the leaky sieve model), copepods can capture particles smaller than the intersetal distance. A lack of the necessary musculature, however, obviates the possibility that intersetal distances could be altered (Richman et al. 1977). Nonetheless, in 'quasi-natural' particle environments (where water samples are passed through a mesh to remove large organisms, then incubated in bottles), copepods located and grazed down peaks in the food size-frequency spectrum over a range of particle sizes (Poulet 1973, 1974 , 1978, Poulet \& Chanut 1975, Poulet \& Marsot 1980). Koehl \& Strickler (1981) and Paffenhöfer et al. (1982) demonstrated that in the low Reynolds number environments within which they exist, copepods are suspension feeders. The second maxillae are effectively paddles, which can push parcels of water containing particles toward the mouth, rather than filtering particles from the water.

Regardless of the mechanism, both size-selective and non-selective feeding have been documented. Cowles (1979) placed these apparently contradictory observations in perspective by proposing that feeding strategies vary with food environment. He demonstrated that, consistent with optimal foraging theory, 
copepods from waters off Peru feed size-selectively when food is abundant and non-selectively when food is scarce. Price et al. (1983) and Price \& Paffenhöfer (1986) clarified the situation further by demonstrating cinematographically that cell-size mediated differences in appendage movements lead to differences in particle capture mechanisms.

Coincident with research on the mechanics of capturing food has been an interest in the cognitive aspects of feeding (food detection, 'decisions' to ingest or reject). Sensory perception exists in both far (remote) and near (at the mouth) fields (Gerritson \& Strickler 1977, Alcaraz et al. 1980, Yen 1988). Strickler \& Bal (1973), Strickler (1982) and Legier-Visser et al. (1986) have articulated models of prey detection from remote chemical and tactile stimuli. Chemoreceptors at the mouthparts, responsible for near-field discrimination of food, were described by Friedman \& Strickler (1975) and Friedman (1980).

Considerable experimental data confirm the existence of sensory perception. Birge (1898) reported that freshwater copepods reject the dinoflagellate Ceratium sp. Calanus finmarchicus also rejects Ceratium sp. (Harvey 1937). Huntley et al. (1986) reported that several dinoflagellate species produce chemical substances that induce avoidance and morbidity in Calanus pacificus; other dinoflagellates are readily ingested (Mullin \& Brooks 1967, Paffenhöfer 1971). Mullin (1963) demonstrated that Calanus helgolandicus ingests exponentially growing algae at higher rates than it does senescent algae. Similarly, Houde \& Roman (1987) reported that Acartia tonsa would ingest more exponentially growing, than senescent, diatoms per unit time. This would result in higher maximum ingestion rates on senescent cells, but larger and nutritionally richer rations from log-phase cells. Paffenhöfer \& Van Sant (1985) showed that the ingestion rate of Eucalanus pileatus varies such that live phytoplankton > dead phytoplankton > fecal pellets. Poulet \& Marsot (1978) reported that copepods ingest microcapsules impregnated with extracts from phytoplankton at higher rates than capsules impregnated with seawater when both capsule types are present in the same container. Cowles et al. (1988) showed that $A$. tonsa distinguishes nutritional quality in mixtures of nutritionally rich and poor cells of the same diatom species. Kiørboe (1989) corroborated these observations, noting further that egg production was influenced by the qualitative aspects of feeding.

Experience with a food also influences particle capture and hence, apparent selective behaviors (Harvey 1937, Price \& Paffenhöfer 1984, Donaghay 1988). Particle rejection, for instance, declines with experience.

\section{THE DIET AND THE FOOD WEB: DEMISE OF THE DIATOM $\rightarrow$ COPEPOD LINK}

Productive pelagic food chains have been characterized as having relatively few links between primary producers and top consumers and by energetic transfer efficiencies on the order of 15 to $20 \%$ (Lindeman 1942, Ryther 1969). Characteristic of such food chains is a direct link between an important group of primary producers, usually the diatoms, and an abundant herbivorous crustacean, such as the copepods. The diatom $\rightarrow$ copepod link has been a key element in the classical pelagic food chain for at least 6 decades. There is strong evidence, however, that this concept is simplistic and misleading. That is not to suggest that copepods do not eat diatoms. Rather, I would argue that attempts to relate feeding and production by means of a single energetic link are contrary to the current understanding of how matter and energy move through ecosystems. There is ample evidence that copepod diets are frequently broad or diverse, composed of a variety of different kinds of foods.

The diatom $\rightarrow$ copepod link arose for several reasons. (1) Diatoms are relatively abundant in the net phytoplankton, especially in productive ecosystems. They were long ago identified as one of the principal foods in copepod diets (Fleming 1939). (2) Dinoflagellates, the other major class of net phytoplankton, grow more slowly than diatoms. They are often scarce in the phytoplankton, relative to diatoms, and some are avoided by copepods. Historically, they have not been considered important in copepod diets. (3) Until recently, the microbial food web was poorly understood, and small phytoplankton (i.e. 2 to $5 \mu \mathrm{m}$ equivalent spherical diameter, ESD) being inefficiently captured by adult copepods, were thought to be nutritionally insignificant. (4) Most calanoid copepods seemed morphologically suited for herbivory (Anraku \& Omori 1963). Because the importance of protozoans in the plankton was not appreciated until recently, most studies of carnivorous feeding by copepods focused on predation of copepod eggs and nauplii (Dagg 1977, Landry 1981, Conley \& Turner 1985. Smith \& Lane 1987). In other than a few species, such as Centropages furcatus (Paffenhöfer \& Knowles 1980), carnivory was thought to be inconsequential to the diets of most calanoid copepods. (5) Although copepods can ingest detritus (Roman 1977, Downs \& Lorenzen 1985), detritivory was considered a secondary source of nutrition (Paffenhöfer \& Van Sant 1985), limited principally to copepods in estuaries (Heinle et al. 1977, Roman et al. 1983).

A new understanding of the relationships between copepods and the food environment has been emerging over the past 2 decades. At least 3 novel concepts 
about trophic structure have affected the general perception of this relationship: (1) energy flows through complex food webs rather than along simple food chains; (2) small phytoplankton and microzooplankton are important in metazoan food webs; and (3) fluxes of materials and energy through ecosystems are governed, in part, by the relationships between food nutritional composition and the nutritional needs of the feeders, rather than simply by the carbon balance between them.
By accepting the notion that energetic pathways in pelagic ecosystems involve complex, highly interactive 'webs', rather than simplistic, linear chains, we are compelled to re-examine the diatom $\rightarrow$ copepod link. As stated above, the problem with this link is not whether copepods eat diatoms but rather the perception that copepod feeding strategies can be characterized by a single, simple interaction.

The overwhelming body of evidence now suggests that copepod diets are, indeed, diverse. Fig. 1, which

(a) Central California, Aug. 2, 1987 - Diatom bloom at front

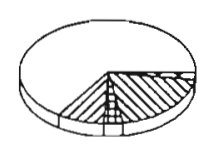

Microplankton

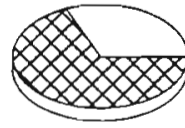

Calanus pacificus

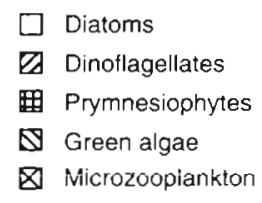

(e) Los Angeles Harbor, Nov. 1986 to Oct. 1987 (mean of 10 expts)

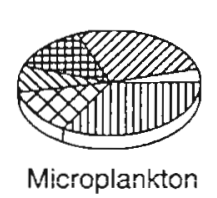

$\square$ Diatoms

Q Dinoflagellates

畔 Tintinnids

D. Aloricate ciliates

区] Metazoans

III Nanoplankton

(b) Irish Sea, May 3, 1989

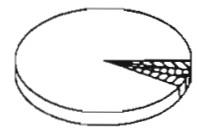

Microplankton

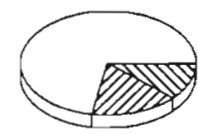

Calanus helgolandicus

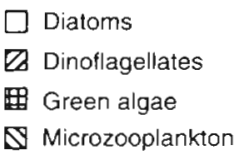

$\$$ Microzooplankton

(f) Los Angeles Harbor, Apr. 1987 - Dinoflagellate bloom

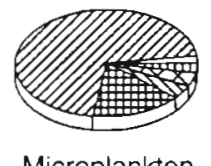

Microplankton

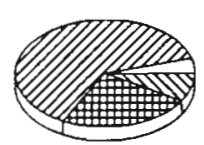

Acartia tonsa

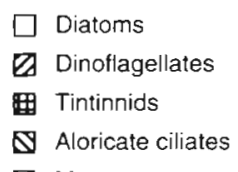

$\bigotimes$ Metazoans

(1I) Nanoplankton

(c) Irish Sea, May 2, 1989

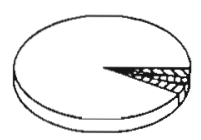

Microplankton

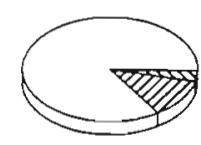

Temora longicornis

\section{$\square$ Diatoms \\ $\square$ Dinoflagellates \\ Green algae \\ $\$$ Microzooplankton}

(d) NE Gulf of Mexico, Mar. 21, 1992

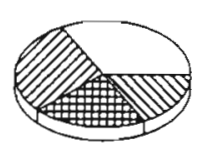

Microplankton

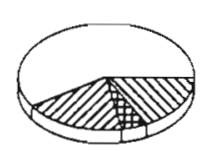

Undinula vulgaris

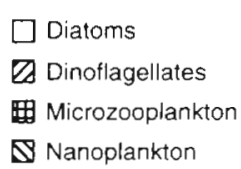

\$ Nanoplankton (g) Los Angeles Harbor, Feb. 1987 - Low production period

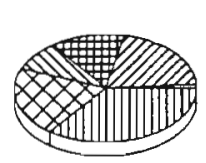

Microplankton

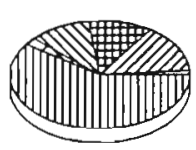

Acartia tonsa

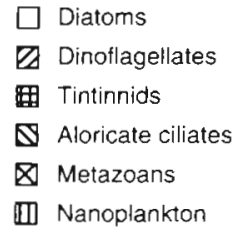

(h) NE Gulf of Mexico, Mar. 21, 1992
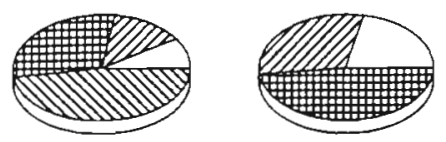

Diatoms

$\square$ Dinoflagellates

Microzooplankton

Nanoplankton

Microplankton Centropages furcatus

Fig. 1. Microplankton (= phytoplankton + microzooplankton) distributions in the food environment and in the diets of copepods from a variety of coastal ecosystems. Microplankton composition and diet of (a) Calanus pacificus off Central California, USA, and of (b) C. helgolandicus and (c) Temora longicornis in the Irish Sea were estimated by pigment analysis techniques described by Kleppel et al. (1988). In these analyses, fucoxanthin, peridinin, 19'-hexanoyl-oxyfucoxanthin, lutein and astaxanthin were used as biomarkers for diatoms, dinoflagellates, prymnesiophytes, green algae and microzooplankton respectively. Units of measurement are ng pigment $\mathrm{l}^{-1}$ for microplankton and ng pigment copepod ${ }^{-1}$ for copepods. Estimates of microplankton composition and diets of (d) Undinula vulgaris and (h) Centropages furcatus in the NE Gulf of Mexico, and of (e, $\mathrm{f} \& \mathrm{~g}$ ) Acartia tonsa in Los Angeles Harbor, were generated from bottle experiments with natural particles that were analyzed by microscopy (see Kleppel 1992). The units of the estimated microplankton concentrations are $\mu \mathrm{g} \mathrm{Cl}^{-1}$ Copepod diets are expressed as $\mu \mathrm{g} \mathrm{Copepod}^{-1} \mathrm{~d}^{-1}$ Data for (b \& c) from Kleppel et al. (1991); data for (e, f \& g) from Kleppel (1992). All other data were previously unpublished 
summarizes some of the available data on the composition of the copepod diet, illustrates that: (1) dietary diversity is the rule rather than the exception, i.e. copepod diets reflect the variety of phytoplankton and microzooplankton taxa present in the environment (e.g. Turner 1984b); and (2) the distributions of food groups in the environment and in the diet are often (but not always) different.

There is little doubt that copepods can be cognizant of the food environment and are exceptionally well adapted to respond behaviorally to variability within that environment. These responses represent feeding strategies which, it will be assumed, have evolved to optimize the nutritional gain realized from the food environment. In the following sections, some aspects of copepod diet composition are discussed and the hypothesis that dietary diversity increases the probability of obtaining a nutritionally complete ration is considered.

\section{COMPOSITION OF THE COPEPOD DIET}

It is well known that diatoms figure prominently in copepod diets, especially in productive (e.g. upwelling) ecosystems (Smith 1982, Schnack \& Elbrächter 1981) and during blooms (Turner 1984c, 1985). The role of dinoflagellates in the copepod diet is more difficult to specify and seems to depend upon the copepod species in question (MoreyGaines 1980), as well as on the species and physio logical status of the dinoflagellate (Table 1). In attempting to understand the role of dinoflagellates (or any group of organisms) in the diet it is necessary to recognize that the dietary importance of dinoflagellate biomass, and the impact of copepod feeding on dinoflagellate biomass in the water column, are not necessarily the same thing. For example, copepod grazing accounts for $<5 \%$ of the dinoflagellate carbon in Chesapeake Bay (USA) during blooms (Sellner \& Olson 1985), but dinoflagellates may contribute a large (though variable, e.g. $<0.2$ to $>60 \%$, average $=33 \%$ in Los Angeles Harbor, California, USA) portion of the carbon in the diets of common estuarine species (Kleppel 1992).

Although the $C: N$ ratios of diatoms tend to be lower than those of dinoflagellates ( $T$. Whitledge pers. comm.), volume-specific concentrations of cellular nutrients were found to be 3 to 3.5 times higher, on average, in axenically cultured dinoflagellates than in diatoms of the same size, grown under identical conditions (Hitchcock 1982). Thus, over a range of particle sizes characteristic of those readily taken by copepods, dinoflagellates are estimated to provide 2 to 6 times more protein, 2.5 to 3.5 times more carbohydrate, and 1.1 to 3.0 times more lipid than diatoms of equivalent volume, under these idealized conditions (Fig. 2). Of course, in nature the nutritional environment is more complex, but it is useful to recognize that basic differences in nutritional value exist between taxonomic groups.

The relationships between the copepod diet and the microbial food web have only recently been elaborated. Protozoans are abundant in the sea and may consume a large portion of the daily primary production (Pomeroy 1974, Capriulo \& Carpenter 1980, Banse 1982, Sherr et al. 1986, Stoecker \& Capuzzo 1990, Gifford 1991, Lessard 1991). Certain protozoans are nutritious to copepods and are readily ingested 

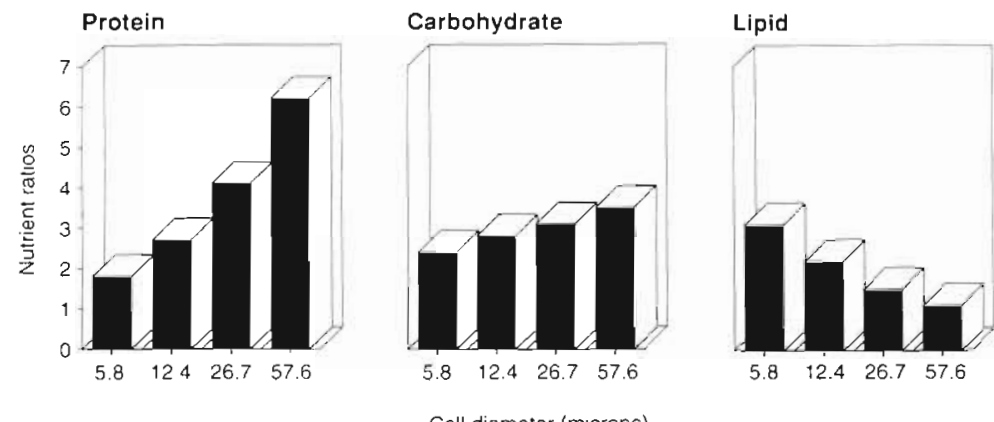

Fig. 2. Dinoflagellate:diatom cellular nutrient ratios calculated over a range of cell sizes that is exploited by calanoid copepods. Ratios are based on idealized estimates derived from relationships between cell volume and protein, carbohydrate and lipid content in axenic algal cultures (Hitchcock 1982). These ratios demonstrate that (1) fundamental differences in chemical composition exist in the phytoplankton which are reflected in taxonomic composition, and (2) nutritional relationships in the phytoplankton vary over the cell size spectrum

(Stoecker \& Egloff 1987, Stoecker \& Capuzzo 1990). Protozoans that ingest nano- and picoplankton may, in turn, be preyed upon by mesozooplankton, transferring previously unavailable energy into the metazoan food web (Sherr et al. 1986) (Table 2).

\section{DIETARY DIVERSITY - ECOLOGICAL SIGNIFICANCE}

Assuming that the copepod diet can be characterized as diverse - consisting of diatoms, dinoflagellates, microzooplankton and other kinds of particles - one must then ask, 'What adaptive advantage does a diverse diet have over a narrow one?' Two advantages are immediately apparent. First, the ability to eat a variety of foods allows an animal to modify its diet with variability in the food environment, an asset in nutritionally dilute environments (Paffenhöfer 1984). Second, a diverse diet may increase the probability that the copepod will obtain a nutritionally complete ration.

Switching between herbivory and carnivory is an example of how copepods can respond to substantial changes in food composition. Switching behavior has been demonstrated in the laboratory (Landry 1981, Stoecker \& Sanders 1985), and, more recently, corroborating evidence has been obtained from field studies (Gifford \& Dagg 1988, Kleppel et al 1988). Field data must be interpreted cautiously given the risk of bias introduced by hydrodynamic variability. However, significant changes in the proportions of plant and animal biomass in the diet (rather than shifts from one extreme to the other) have been documented over relatively short periods of time. Typical frequencies of variability in the diet are on the order of hours to days, often in apparent response to changes in the food environment (Fig. 3). The effect of dietary switching on secondary production has not been quantified, though logically, the ability to obtain at least some minimal level of nutrition from a variety of food sources, would seem advantageous

The particles that copepods eat vary in nutritional composition (Parsons et al. 1977, Hitchcock 1982, Stoecker \& Capuzzo 1990) and feeding strategies which enable the copepod to sample a variety of foods may permit nutrients lacking in one source to be

Table 2. Evidence of carnivory among small calanoid copepods

\begin{tabular}{|llll|}
\hline Species & Relative importance in diet & Details & Source \\
\hline $\begin{array}{l}\text { Centropages hamatus } \\
\text { C. } \text { typicus }\end{array}$ & $33 \%$ of diet & Copepod nauplii & Conley \& Turner (1985) \\
C. typicus & $100 \%$ of body C d ${ }^{-1}$ & Fish larvae & Turner et al. (1985) \\
& $0-78 \%$ of lab diet & $\begin{array}{l}\text { Eggs of own species, with and } \\
\text { without other food }\end{array}$ & Smith \& Lane (1987) \\
Acartia hudsonica & $73 \%$ of lab diet & $\begin{array}{l}\text { Euterpina pectinus + Gonyaulax } \\
\text { tamarensis }\end{array}$ & Turner \& Anderson (1983) \\
A. tonsa & Up to ca $80 \%$ of lab diets & Various microzooplankton/ & Stoecker \& Sanders (1985). \\
A. tonsa & $3-41 \%$ of daily ration & algal mixtures & Stoecker \& Egloff (1987) \\
A. tonsa & $0-70 \%$ & Natural microplankton & Gifford \& Dagg (1988) \\
Calanus pacificus & $22-94 \%$ & Natural microplankton & Kleppel (1992) \\
C. pacificus & Up to ca 100\% of lab diet & Copepod nauplii et al. (1988) \\
C. helgolandicus & $33 \%$ & Natural microplankton & Landry (1981) \\
Temora longicornis & $54 \%$ & Natural microplankton & Kleppel et al. (1991) \\
Clausocalanus spp. & $55-97 \%$ & Natural microplankton & Kleppel et al. (1988) \\
\hline
\end{tabular}



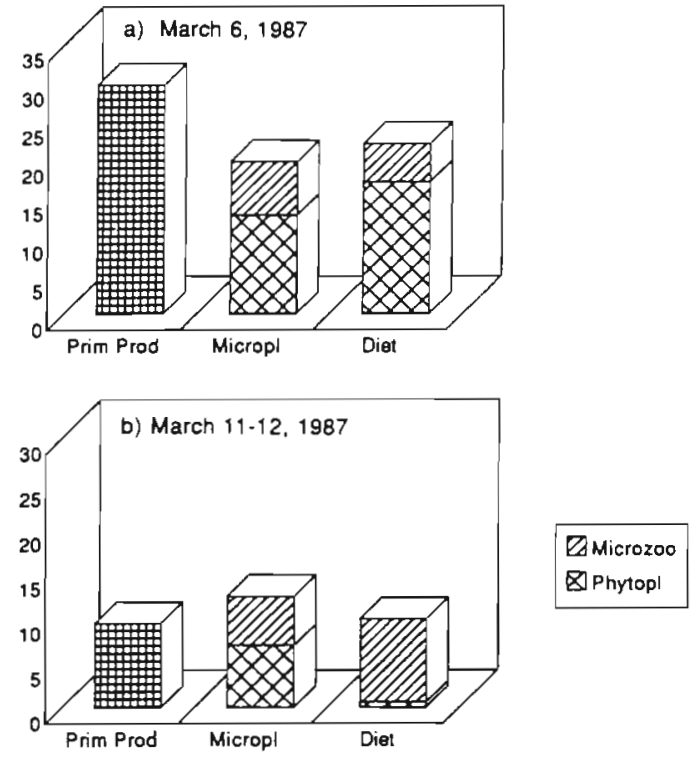

Fig. 3. Calanus pacificus. Example of relatively rapid shifts in observed diet coincident with variation in the food environment. Study was conducted off Santa Catalina Island, California, USA. Samples were collected in close spatial proximity of

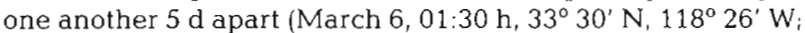
March 11-12, ca 00:00 h, 33 $30^{\prime} \mathrm{N}, 118^{\circ} 23^{\prime} \mathrm{W}$ ). (a) On March

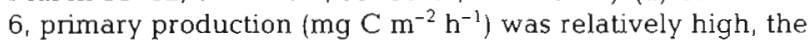
microplankton was dominated by phytoplankton (biomass expressed as $\mathrm{mg} \mathrm{C} \mathrm{m}{ }^{-2}$, divided by 100 for scaling purposes), and the copepod fed primarily on phytoplankton (diet expressed as gut fullness, as ng C copepod ${ }^{-1}$, multiplied by 10 ). (b) On March 11-12, primary production had declined to onethird its previous level, the phytoplankton biomass in the microplankton was half of its previous level (though the microzooplankton biomass was unchanged) and the diet of C. pacificus was dominated by microzooplankton. (After Kleppel et al. 1988)

obtained from others. For example, Acartia tonsa survived longer and grew at higher rates when its diet consisted of a mixture of the diatom Thalassiosira weissflogii and detritus than when each food was provided alone (Roman 1984). Although $T$. weissflogii provided a majority of the nutrients required by the copepod, the detritus provided $C_{18}$ saturated and unsaturated fatty acids, and several amino acids (e.g. asparagine-glutamine, serine, taurine, tyrosine) that were scarce or lacking in the diatom. The significance of these findings is best appreciated in light of evidence that copepods seem incapable of storing amino acids (Goulden \& Place in press). When dietary amino acid concentrations are inadequate for protein catabolism, deamination occurs and the ration is lost through ammonium excretion.

In another study, regression analyses were performed to determine the relationships between the egg production rate of Acartia tonsa and the daily ingestion rate of the copepod on various kinds of phyto- and

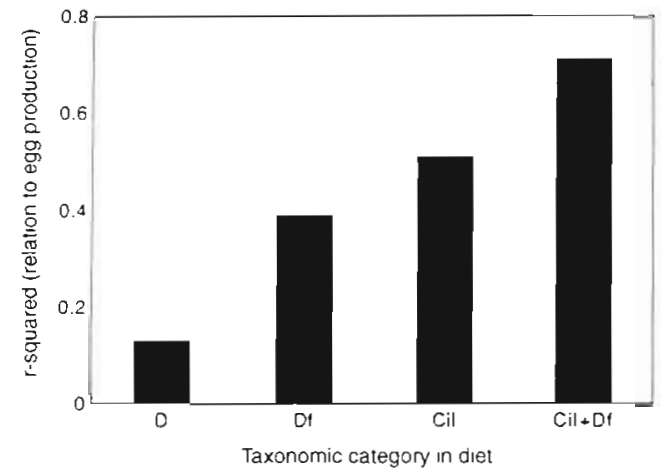

Fig. 4. Acartia tonsa. Proportion of variance explained by the relationship between egg production and various components of the diet of $A$. tonsa off southern California, USA, during 10 experiments between November 1986 and October 1987. The various biomass (as carbon) components of the diet are regressed against egg production, the bars in the figure representing the $r^{2}$ for the regression. Taxonomic categories are: D, diatoms; Df, dinoflagellates; Cil, ciliates (tintinnids + aloricate forms); Cil+Df, sum of ciliate + dinoflagellate biomass. (After Kleppel et al. 1991)

microzooplankton in quasi-natural food environments (Kleppel et al. 1991). The correlation of egg production to dietary microplankton biomass increased as diatoms $<$ dinoflagellates < ciliates < dinoflagellates + ciliates (Fig. 4). [The addition of diatom biomass to the last regression did not improve the correlation $\left.\left(r^{2}=0.60\right)\right]$. Apparently, the combination of dinoflagellates and ciliates in the diet contributed more than each food individually to egg production (Kleppel et al. 1991). Diatom biomass, which was not systematically associated with egg production, may serve other metabolic functions (see below).

Similarly, Støttrup \& Jensen (1990) observed that Acartia tonsa ingests the small green alga Dunaliella tertiolecta in phytoplankton mixtures but ingestion is reduced and egg production declines when it is offered as a unialgal diet. The authors demonstrated that, while rich in total lipids, $D$. tertiolecta lacks polyunsaturated fatty acids larger than $C_{18}$, unlike other, small, algal species, which do support egg production.

\section{FEEDING STRATEGIES AND THE NUTRITIONAL ENVIRONMENT}

Controlled experiments have been conducted in the laboratory to ascertain the extent to which copepod feeding behaviors are consistent with the predictions of optimal foraging theory (DeMott 1989). The results of such studies frequently corroborate the theory (Cowles et al. 1988, DeMott 1989). In nature, however, the taxonomic and biochemical complexity of the food 
Table 3. Sumnary of data on the chemical (protein, lipid, carbohydrate) compositions of copepods. nd: no data

\begin{tabular}{|lcccl}
\hline Category & \multicolumn{4}{c}{ Chemical composition as \% of dry wt } \\
& Protein & Lipid & Carbohydrate & Source \\
\hline Gulf of Mexico copepods & $29.6-67.7$ & $2.9-56.3$ & nd & Morris \& Hopkins (1983) \\
Pleuromamma abdominalis & $50.3-57.9$ & $8.3-6.8$ & nd & Morris \& Hopkins (1983) \\
Mixed copepods & 59.0 & 7.0 & 20.0 & Brandt (1898), cited in Raymont (1983) \\
Calanus finmarchicus & $30.0-77.0$ & $10.5-47.0$ & nd & Orr (1934) \\
C. helgolandicus & 75.2 & 11.0 & nd & Nakai (1955), cited in Raymont (1983) \\
C. helgolandicus & 43.0 & 46.0 & 9.0 & Vinogradova (1964), cited in Raymont (1983) \\
C. helgolandicus & nd & 28.0 & nd & Lee et al. (1972) \\
Acartia clausi & 79.3 & 2.7 & nd & Nakai (1955), cited in Raymont (1983) \\
A. tonsa & 27.7 & 19.5 & 25.4 & Houde \& Roman (1987) \\
& & & & \\
Mean of all data & 46.2 & 20.0 & 18.1 & 6.8 \\
Standard deviation & 24.9 & 17.7 & 37.6 & \\
\% Coefficient of variation & 53.9 & 88.5 & & \\
\hline
\end{tabular}

environment make it difficuit to apply such models (Kleppel 1992). In part, the difference between the laboratory and the natural environment is that in the laboratory one can create clear distinctions within the food environment (e.g. nutritious vs non-nutritious food). In nature, such distinctions are not as clearcut; a food item may contain some nutrients but not others. It may be most effective, therefore, to describe natural food environments on the basis of their nutritional characteristics, and to describe the feeding activities of copepods as responses to nutrient distributions.

The emphasis of studies on copepod nutrition has been on individual nutrients, most notably, various forms of nitrogen (i.e. particulate organic $\mathrm{N}$, amino acids, protein). Interest in nitrogen stems, in part, from its perceived importance to phytoplankton growth in the sea. Checkley (1980) was one of the first to suggest that nitrogen (as protein) ultimately limits copepod production in many areas. This hypothesis has, in fact, been supported in several coastal and nearshore ecosystems (Checkley 1980, Ambler 1985, Checkley et al. 1992). In Acartia tonsa, the functional ingestion response varies directly as protein content in the food environment (Houde \& Roman 1987). A. tonsa takes up protein from its food more rapidly than other nutrients (Roman 1991) and both the ingestion and egg production rates of $A$. tonsa may be influenced by particulate organic nitrogen concentrations (Kiørboe 1989).

Nutrients, however, function interactively as well as individually. Certain lipids, for example, facilitate protein metabolism (Gallagher et al. 1979, Roman 1984), and the nutritional requirements of animals change with season, age, and physiological response to environmental variability. Therefore, the feeding strategy must simultaneously address 2 related functions: optimizing the acquisition of scarce but important nutrients, and satisfying the immediate nutritional and physiological needs of the animal. For example, during all stages of growth, and especially in early life history, carbon, as protein, is taken up at a high rate by Acartia tonsa. However, adult females put carbon into lipid at higher rates than do immature copepodites (Roman 1991j.

An examination of the chemical (nutritional) compositions of copepods (Table 3) shows that while chemical composition is, in general, quite variable, the lipid pool is by far the most variable $(\mathrm{CV}=89 \%$, as opposed to $54 \%$ for protein and $36 \%$ for carbohydrates). Structural and metabolic proteins are essential for all animals and their concentrations vary as the animal grows. Lipids, on the other hand, are used to store energy, and the specific energy storage needs of copepods can vary enormously through life. Lipid biochemistry subdivides the Copepoda on the basis of ontogeny (i.e. certain lipids are taken up rapidly for egg production; Roman 1991), activity (lipid storage may determine diapause success; Ohman 1987), recent feeding history (Hakanson 1984) and biogeography (offshore species generally store lipids, nearshore species tend not to; Dagg 1977, Miller et al. 1977).

The proper way of describing the nutritional environment depends upon the question being addressed and on the forms in which nutrients are utilized by the animals. For example, different lipids perform vastly different functions and, as Støttrup \& Jensen (1990) showed, some phytoplankton, while rich sources of total lipids, may lack the specific lipids critical to certain functions (e.g. egg production). Another example, shown in Fig. 5a to $c$, also illustrates this point, and emphasizes the relationship between the nutritional characteristics of the food environment and the nutritional requirements of the copepod. Fig. 5a, b shows that, while the amino acid distributions of the dinoflagellate Amphidinium carteri and the diatom Thalassiosira 
weissflogii are similar, only the diatom contains the metabolic amino acid, ornithine (used in the Krebs and urea cycles). Ornithine is also present in the copepod Calanus pacificus (Fig. 5c). Thus, this copepod, feeding on $A$. carteri alone, would be unable to obtain for ornithine [note the implications in the context of the observations of Goulden \& Place (in press), cited abovel. Obviously, measuring total protein concentrations in the food environment would be inadequate to explain differences in the metabolism of C. pacificus caused by differences in amino acid composition of the algae. Thus, subtle differences in the nutritional structures of food environments can have significant ecological implications.

\section{CONCLUSION}

The purpose of feeding is to obtain the energy and materials needed to function, survive and ultimately reproduce. Athough feeding strategies are limited by the sensory-motor capabilities of the species, they have been evolved to optimize nutritional gain for the individual, and thereby to enhance the fitness of the population.

To this end copepod diets tend to be diverse, reflecting the complexity of the pelagic food web. While classical trophic dynamic models emphasized simplicity, to minimize the leakage of energy from the chain, more recent ideas depict a series of alternative pathways along which matter and energy can travel to higher trophic levels. Consistent with this paradigm, diversity in copepod diets provides alternative pathways for obtaining required nutrients and increases the probability of obtaining a nutritionally complete ration. Production and nutrition are related, and nutritionally complete diets would seem to enhance the probability of success for the individual, and ultimately the population, within the environment.

The notions that the ecological goal of foraging behavior is to obtain a nutritionally complete ration, and that dietary diversity tends to optimize the probability of realizing that goal are not, in themselves, new concepts. Complete nutrition is a key element in aquaculture, and is intuitive in much of biology and ecology. Yet the point of this paper differs in fundamental ways from the tenets of aquaculture, and ecologists have only recently begun to acquire the tools to investigate the details of nutrition in marine ecosystems. While in aquaculture one seeks to understand nutrition in order to maximize the output, this paper has focused on understanding how animals respond to diversity and variability (attributes lacking or minimized in aquaculture) in the food environment. In doing so, one hopes to gain some basic appreciation and predictive sense of a

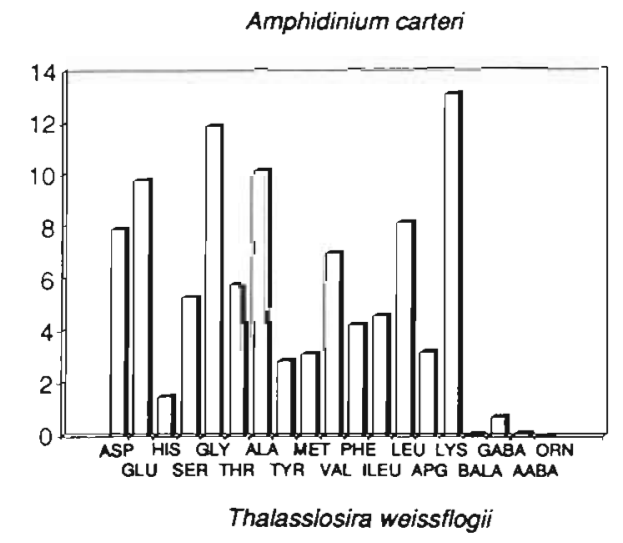

b

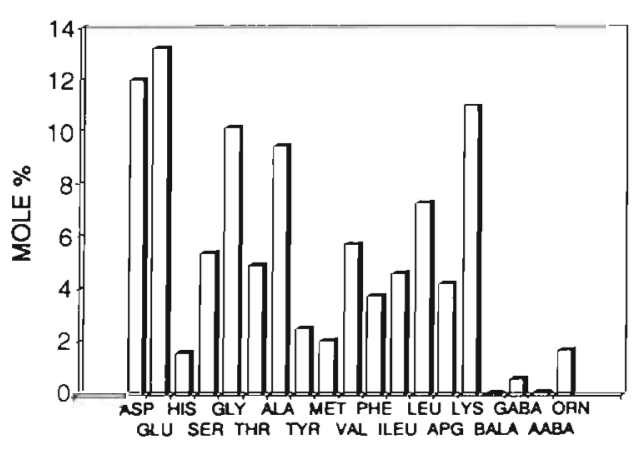

C

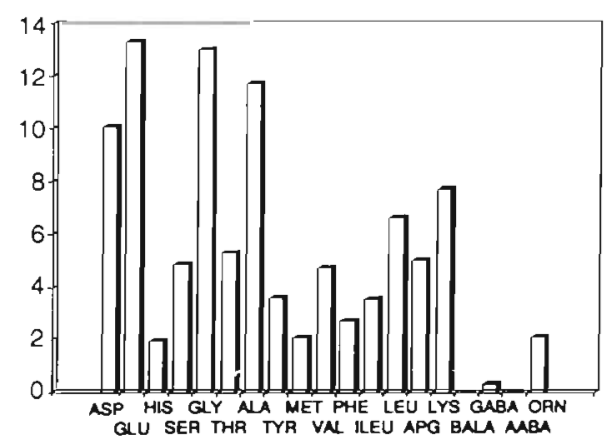

Fig. 5. Amino acid distributions in (a) Amphidinium carteri (Dinophyceae), (b) Thalassiosira weissflogii (Bacillariophyceae) and (c) Calanus pacificus (Copepoda: Crustacea). Histograms plotted with data from Cowie \& Hedges (1992)

the partitioning of resources in marine ecosystems. Although the abilities to measure amino acids and lipid classes are not yet routine in most laboratories, the availability of the necessary technology is on the rise. Efforts to understand and model copepod feeding by combining concepts of nutritional biochemistry and optimal foraging theory have been largely successful, though limited (by the lack of technology) to relatively simple, laboratory experiments. As the technology becomes available, more realistic, complex and revealing experiments will be feasible.

The concepts discussed in this paper, dietary diversity and nutritional optimization, are readily illustrated 
with copepods. However, these concepts are derived from a more general set of ideas about trophic dynamic processes, namely that matter and energy travel along diverse rather than simple paths. It is quite reasonable that diversity may be characteristic of animal diets, and not unique to a single group of crustaceans. Copepods may simply be good examples of a more general phenomenon in nature.

Acknowledgements. I am grateful to G.-A. Paffenhöfer, W. T. Peterson, M. E. Clarke, E. J. Lessard, G. L. Stone and 2 anonomous reviewers for their helpful comments on various drafts of the manuscript. I also thank M. R. Roman C. Tomas, $K$. Carter and C. Burkart for the many productive discussions that contributed to the formulation of ideas presented in this paper. The assistance of K. Maxson with the graphics is greatly appreciated. Support for the time necessary to prepare this review as well as for the collection of much of the data presented in this paper was provided by the University of Georgia Marine Institute visiting scientist program, by NSF grants OCE 8822521 and OCE 9103205, NOAA grant NA86AA-DSG119, and by the Florida Department of Natural Resources under contract C-7036. This paper is dedicated to Reuben Lasker, who significantly influenced my thinking about zooplankton diets and their measurement. Contribution No. 730, University of Georgia Marine Institute.

\section{LITERATURE CITED}

Alcaraz, M., Paffenhöfer, G.-A., Strickler, J. R. (1980). Catching the algae: a first account of visual observations on filter-feeding calanoids. In: Kerfoot, W. C. (ed.) Evolution and ecology of zooplankton communities. University of New Hampshire, Hanover, p. 241-248

Ambler, J. W. (1985). Seasonal factors affecting egg production and viability of eggs of Acartia tonsa Dana from East Lagoon, Galveston, Texas. Estuar. coast. Shelf Sci. 20: $743-760$

Anraku, M., Omori, M. (1963). Preliminary survey of the relationship between feeding habit and the structure of the mouthparts of marine copepods. Limnol. Oceanogr. 8: $116-126$

Banse, K. (1982). Cell volume, maximal growth rates of unicellular algae and ciliates, and the role of ciliates in the marine pelagial. Limnol. Oceanogr. 27: 1059-1071

Bartram, W. C. (1980). Experimental development of a model for the feeding of neritic copepods on phytoplankton. J. Plankton Res. 3: 25-51

Birge, E. A. (1898). Plankton studies on Lake Mendota. II. The crustacea of the plankton. Trans. Wis. Acad. Sci. Arts Lett. 11. $274-448$

Boyd, C. M. (1976). Selection of particles by filter-feeding copepods: a plea for reason. Limnol. Oceanogr. 21: $175-180$

Boyd, C. M., Smith, S. L., Cowles, T. J. (1980). Grazing patterns of copepods in the upwelling system off Peru. Limnol. Oceanogr. 25: 583-596

Cannon, H. G. (1928). On the feeding mechanisms of the copepods Calanus finmarchicus and Diaptomus gracilis. Brit. J. exp. Biol. 6: 131-144

Capriulo, G. M., Carpenter, E. J. (1980). Grazing by $35 \mu \mathrm{m}$ to $202 \mu \mathrm{m}$ micro-zooplankton in Long Island Sound. Mar. Biol. 56: 319-326
Checkley, D. M. Jr (1980). Food limitation of egg production by a marine planktonic copepod in the sea off southern California. Limnol. Oceanogr. 25: 991-998

Checkley, D. M. Jr, Dagg, M. J., Uye, S. (1992). Feeding, excretion and egg production by individuals and populations of the marine planktonic copepods Acartia spp. and Centropages furcatus. J. Plankton Res. 14: 71-96

Conley, W. J., Turner, T. J. (1985). Omnivory by the coastal marine copepods Centropages hamatus and Labidocera aestiva. Mar. Ecol. Prog. Ser. 21: 113-120

Conover, R. J., Durvasula, R., Roy, S., Wang, R. (1986). Probable loss of chlorophyll derived pigments during passage through the gut of zooplankton, and some of the consequences. Limnol. Oceanogr. 31: 878-887

Cowie, G. L., Hedges, J. I. (1992). Sources and reactivities in a coastal marine environment. Limnol. Oceanogr. 37: $703-724$

Cowles, T. J. (1979). The feeding response of copepods from the Peru upwelling system: food size selection. J. mar. Res. 13: $601-622$

Cowles, T. J., Olson, R. J., Chisolm, S. W. (1988). Food selection by copepods: discrimination on the basis of food quality. Mar. Biol. 100: $4 \hat{i}-49$

Cowles, T. J., Strickler, J. R. (1983). Characterization of feeding activity patterns in the planktonic copepod Centropages typicus Kroyer under various food conditions. Limnol. Oceanogr. 28: 106-115

Dagg, M. (1977). Some effects of patchy food environments on copepods. Limnol. Oceanogr. 22: 99-107

Dagg, M. R., Grill, D. W. (1980). Natural feeding rates of Centropages typicus females in the New York Bight. Limnol. Oceanogr. 25: 597-609

Dagg, M. R., Wyman, K. D. (1983). Natural ingestion rates of the copepods Neocalanus plumchrus and N. cristatus calculated from gut contents. Mar. Ecol. Prog. Ser. 13: 37-46

Dam, H. G., Peterson, W. T. (1988). The effect of temperature on the gut clearance rate constant of planktonic copepods. J. exp. mar. Biol. Ecol. 123: 1-14

DeMott, W. (1989). Optimal foraging theory as a predictor of chemically mediated food selection by suspension-feeding copepods. Limnol. Oceanogr. 34: 140-154

Donaghay, P. L. (1988). The role of temporal scales of acclimation food quality and trophic dominance in controlling the evolution of copepod feeding behavior. Bull. mar. Sci. 43: 469-85

Donaghay, P. L., Small, L. F. (1979). Food selection capabilities of the estuarine copepod Acartia clausi. Mar. Biol. 52 $137-146$

Downs, J. N., Lorenzen, C. J. (1985). Carbon:pheopigment ratios of zooplankton fecal pellets as an index of herbivorous feeding. Limnol. Oceanogr. 30: 1024-1036

Durbin, A. G., Durbin, E. G., Wlodarczyk, E. (1990). Diel feeding behavior in the marine copepod Acartia tonsa in relation to food availability. Mar. Ecol. Prog. Ser. 68: 23-45

Durbin, E. G., Durbin, A. G., Smayda, T J., Verity, P. G (1983). Food limitation of production by adult Acartia tonsa in Narragansett Bay, Rhode Island. Limnol. Oceanogr. 28: 1199-1213

Easterly, C, O. (1916). The feeding habits and food of pelagic copepods and the question of nutrition by organic substances in solution in the water. Univ. Calif. Publ. Zool. 16: $171-184$

Fleming, R. H. (1939). The control of diatom populations by grazing. J. Cons. perm. int. Explor. Mer 14: 210-227

Friedman, M. M. (1980). Comparative morphology and functional significance of copepod receptors and oral structures. In: Kerfoot, W. C. (ed.) Evolution and ecology of 
zooplankton communities. University of New Hampshire, Hanover, p. 185-197

Friedman, M. M., Strickler, J. R. (1975). Chemoreceptors and feeding in calanoid copepods (Arthropoda: Crustacea). Proc. natl Acad. Sci. 72: 4185-4188

Frost, B. W. (1972). Effects of size and concentration of food particles on the feeding behavior of the marine planktonic copepod Calanus pacificus. Limnol. Oceanogr. 18: $805-815$

Frost, B. W. (1977). Feeding behavior of Calanus pacificus in mixtures of food particles. Limnol. Oceanogr. 22: 472-492

Gallagher, M. L., Bayer, R. C., Leavitt, D. F., Rittenburg, J. H. (1979). Effects of protein-energy ratios on the growth of American lobsters (Homarus americanus). Proc. Wld Maricult. Soc. 10: 746-750

Gerritsen, J., Strickler, J. R. (1977). Encounter probabilities and community structure in zooplankton: a mathematical model. J. Fish. Res. Bd Can. 34: 73-82

Gieskes, W. W. C., Engelkes, M. M., Kraay, G. W. (1991). Degradation of diatom chlorophyll to colourless compounds during copepod grazing. Hydrobiol. Bull. 25: $65-72$

Gifford, D. J. (1991). The protozoan-metazoan trophic link in pelagic ecosystems. J. Protozool. 38: 81-86

Gifford, D. J., Dagg, M. J. (1988). Feeding of the estuarine copepod Acartia tonsa Dana: carnivory vs. herbivory in natural microplankton assemblages. Bull. mar. Sci. 43: $458-468$

Goulden, C. E., Place, A. R. (in press). Lipid accumulation and allocation in daphnid Cladocera. Bull. mar. Sci. 53

Hakanson, J. L. (1984). Long and short term feeding condition in field caught Calanus pacificus as determined from lipid content. Limnol. Oceanogr. 29: 794-804

Harbison, G. R., McAlister, V. L. (1980). Fact and artifact in copepod feeding experiments. Limnol. Oceanogr. 25: 971-981

Hardy, A. C. (1924). The herring in relation to its animate environment. Part I: The food and feeding habits of the herring with special reference to the east coast of England. Fish. Invest., Lond. (Ser. II) 7: 1-53

Hargrave, B. T., Geen, G. H. (1970). Effects of copepods grazing on two natural phytoplankton populations (A. tonsa). J. Fish. Res. Bd Can. 30: 1317-1326

Harris, R. P., Paffenhöfer, G.-A. (1976). Feeding, growth and reproduction of the marine planktonic copepod Temora longicornis Muller. J. mar. biol. Ass. U.K. 56: 675-690

Harvey, H. W. (1937). Note on selective feeding by Calanus. J. mar. biol. Ass. U.K. 22: 97-100

Haury, L. R., Pieper, R. E. (1988). Zooplankton: scales of biological and physical events. In: Soule, D. F., Kleppel, G. S. (eds.) Marine organisms as indicators. Springer-Verlag, New York, p. 35-73

Head, E. J. H., Harris, L. R. (1992). Chlorophyll and carotenoid transformation and destruction by Calanus spp. grazing on diatoms. Mar. Ecol. Prog. Ser. 86: 229-238

Heinle, D. R. (1969). Temperature and zooplankton. Chesapeake Sci. 10: 186-209

Heinle, D. R., Harris, R. P., Ustach, J. F., Flemer, D. A. (1977). Detritus as food for estuarine copepods. Mar. Biol. 40: 341-353

Hitchcock, G. L. (1982). A comparative study of the sizedependent organic composition of marine diatoms and dinoflagellates. J. Plankton Res. 4: 363-377

Hopkins, T. L. (1985). Food web of an Antarctic midwater ecosystem. Mar. Biol. 89: 197-212

Hopkins, T. L. (1987). Midwater food web in McMurdo Sound, Ross Sea, Antarctica. Mar. Biol. 96: 93-106
Houde, S., Roman, M. R. (1987). Effects of food quality on the functional ingestion response of the copepod Acartia tonsa. Mar. Ecol. Prog. Ser. 40: 69-77

Huntley, M. E., Sykes, P., Rohan, S., Marin, V. (1986). Chemically mediated rejection of dinoflagellate prey by the copepods Calanus pacificus and Paracalanus parvus: mechanisms, occurrence, significance. Mar. Ecol. Prog. Ser. 28: 105-120

Huntley, M. R. (1981). Nonselective, nonsaturated feeding by three calanid copepod species in the Labrador Sea. Limnol. Oceanogr. 26: 831-842.

Kerfoot, W. C. (ed.) (1980). Evolution and ecology of zooplankton communities. University of New Hampshire, Hanover

Kiørboe, T (1989). Phytoplankton growth rate and nitrogen content: implications for feeding and fecundity in a herbivorous copepod. Mar. Ecol. Prog. Ser. 55: 229-234

Kiørboe, T., Mohlenberg, F., Nicholajsen, H. (1982). Ingestion rate and gut clearance in the planktonic copepod Centropages hamatus (Lilleborg) in relation to food concentration and temperature. Ophelia 21: 181-194

Kiørboe, T., Møhlenberg, F., Riisgård, H. U. (1985). In situ feeding rates of planktonic copepods: a comparison of four methods. J. exp. mar. Biol. Ecol. 88: 67-81

Kiørboe, T., Tiselius, P. T. (1987). Gut clearance and pigment destruction in a herbivorous copepod, Acartia tonsa, and the determination of in situ grazing rates. J. Plankton Res. 9: $525-534$

Kleppel, G. S. (1988). Plant and animal pigments as trophodynamic indicators. In: Soule, D. F., Kleppel, G. S. (eds.) Marine organisms as indicators. Springer-Verlag, New York, p. 73-90

Kleppel, G. S. (1992). Environmental regulation of feeding and egg production by Acartia tonsa off southern California. Mar. Biol. 112: 57-65

Kleppel, G. S., Frazel, D. W., Pieper, R. E., Holliday, D. V. (1988). Natural diets of zooplankton off southern California. Mar. Ecol. Prog. Ser. 49: 231-241

Kleppel, G. S., Holliday, D. V., Pieper, R. E. (1991). Trophic interactions between copepods and microplankton: a question about the role of diatoms. Limnol. Oceanogr. 36 : $172-178$

Kleppel, G. S., Pieper, R. E. (1984). Phytoplankton pigments in the gut contents of planktonic copepods from coastal waters off southern California. Mar. Biol. 78: 193-198

Koehl, M. A., Strickler, J. R. (1981). Copepod feeding currents: food capture at low Reynolds number. Limnol. Oceanogr. 26: 1062-1073

Landry, M. R. (1981). Switching between herbivory and carnivory by the planktonic marine copepod Calanus pacificus. Mar. Biol. 65: 77-82

Lasker, R. (1988). Food chains and fisheries: an assessment after 20 years. In: Rothschild, B. J. (ed.) Toward a theory on biological-physical interactions in the world ocean. Kluwer, Boston, p. 173-182

Lee, R. F., Nevenzel, J. C., Paffenhöfer, G.-A. (1972). The presence of wax esters in marine planktonic copepods. Naturwissenschaften 59: 406-411

Legendre, L., Demers, S. (1984). Towards dynamic biological oceanography and limnology. Can. J. Fish. Aquat. Sci. 41: $2-19$

Legier-Visser, M. F., Mitchell, J. G., Okubo, A., Fuhrman, J. A. (1986). Mechanoreception in calanoid copepods. A mechanism for prey detection. Mar. Biol. 90: 529-535

Lessard, E. J. (1991). The trophic role of heterotrophic dinoflagellates in diverse marine environments. Mar. Microb. Fd Webs 5: 49-58 
Lindeman, R. L. (1942). The trophic-dynamic aspect of ecology. Ecology 23: 399-418

Lopez, M. D. G., Huntley, M. E., Sykes, P. F. (1988). Pigment destruction by Calanus pacificus: impact on the estimation of water column fluxes. J. Plankton Res. 10: 715-734

Lowndes, A. G. (1935). The swimming and feeding of certain Calanoid copepods. Proc. Zool. Soc. Lond. 687-715

Mackas, D., Bohrer, R. (1976). Fluorescence analysis of zooplankton gut contents and an investigation of diel feeding patterns. J. exp. mar. Biol. Ecol. 25: 77-85

Marshall, S. M., Orr, A. P. (1955). The biology of a marine copepod, Calanus pacificus (Gunnerus). Oliver and Boyd, Edinburgh

Mayzaud, P., Poulet, S. A. (1978). The importance of the time factor in the response of zooplankton to varying concentrations of naturally occurring particulate matter. Limnol. Oceanogr. 23: 1144-1154

Miller, C. B., Johnson, J. K., Heinle, D. R. (1977). Growth rules in the marine copepod genus Acartia. Limnol. Oceanogr. 22: $326-334$

Morey-Gaines, G. (1980). The ecological role of dinoflagellate blooms in the Los Angeles-Long Beach Harbor Ph.D. dissertation, Universily of Southern Caijfornia, Los Angeles

Morris, M. J., Hopkins, T. L. (1983). Biochemical composition of crustacean zooplankton from the eastern Gulf of Mexico. J. exp. mar. Biol. Ecol. 69: 1-19

Mullin, M. M. (1963). Some factors affecting the feeding of marine copepods of the genus Calanus. Limnol. Oceanogr. 8: $239-250$

Mullin, M. M., Brooks, E. R. (1967). Laboratory culture, growth rate and feeding behavior of a planktonic marine copepod. Limnol. Oceanogr. 12: 657-666

Mullin, M. M., Stewart, E. F., Fulgister, F. J. (1975). Ingestion by planktonic grazers as a function of concentration of food. Limnol. Oceanogr. 20: 259-262

Nival, P., Nival, S. (1973). Efficacité de filtration des copepodes planctoniques. Ann. Inst. Oceanogr. 49: 135-144

Nival, P., Nival, S. (1976). Particle retention efficiencies of an herbivorous copepod Acartia clausi (adult and copepodite stages): effects on grazing. Limnol. Oceanogr. 21: 24-38

Ohman, M. (1987). Energy sources for recruitment of the subantarctic copepod Neocalanus tonsus. Limnol. Oceanogr. 32: $1317-1330$

Orr, A. P. (1934). On the biology of Calanus finmarchicus. IV: Seasonal changes in the weight and chemical composition of Calanus from Loch Fyne. J. mar. biol. Ass. U.K. 20: $613-632$

Paffenhöfer, G.-A. (1970). Cultivation of Calanus helgolandicus under controlled conditions. Helgoländer wiss. Meeresunters 20: 346-359

Paffenhöfer, G.-A. (1971). Grazing and ingestion rates of nauplii, copepodids and adults of the marine planktonic copepod Calanus helgolandicus. Mar. Biol. 11: 286-298

Paffenhöfer, G.-A. (1984). Food ingestion by the marine planktonic copepod Paracalanus in relation to abundance and size distribution of food. Mar. Biol. 80: 323-333

Paffenhöfer, G.-A. (1988). Feeding rates and behavior of zooplankton. Bull. mar. Sci. 43: 430-445

Paffenhofer, G.-A., Harris, R. P. (1976). Feeding, growth and reproduction of the marine planktonic copepod Pseudocalanus elongatus Boeck. J. mar. biol. Ass. U.K. 56: $327-344$

Paffenhöer, G.-A., Knowles, P. (1980). Omnivorousness in marine planktonic copepods. J. Plankton Res. 2: 355-365

Paffenhofer, G.-A. Strickler, J. R., Alcaraz, M. (1982). Suspension feeding by herbivorous calanoid copepods: a cinematographic study. Mar. Biol. 67: 193-199

Paffenhöfer, G.-A., Van Sant, K. B. (1985). The feeding response of a marine planktonic copepod to quantity and quality of particles. Mar. Ecol. Prog. Ser. 27: 55-65

Parsons, T. R, LeBrasseur, R. J., Fulton, J. P. (1967). Some observations on the dependence of zooplankton grazing on cell size and concentration of phytoplankton. J. Oceanogr. Soc. Jap. 23: 10-17

Parsons, T. R., Takahashi, M., Hargrave, B. (1977). Biological oceanographic processes, 2nd edn. Pergamon, New York

Penry, D. L., Frost, B. W. (1990). Re-evaluation of the gut fullness (gut fluorescence) method for inferring ingestion rates of suspension feeding copepods. Limnol. Oceanogr. 35: 1207-1214

Penry, D. L., Frost, B. W. (1991). Chlorophyll a degradation by Calanus pacificus: dependence on ingestion rate and digestive acclimation to food resources. Limnol. Oceanogr. 36: $147-158$

Pomeroy, L. R. (1974). The ocean's food web, a changing paradigm. BioSci. 24: 499-504

Poulet, S. A. (1973). Grazing by Pseudocalanus minutus on naturally occurring particulate matter. Limnol. Oceanogr. 18: $564-573$

Poulet, S. A. (1978). Comparison of five coexisting species of marine copepods feeding on naturally occurring particulate matter. Limnol. Oceanogr. 23: 1126-1143

Poulet, S. A., Chanut, J. P. (1975). Non-selective feeding of Pseudocalanus minutus. J. Fish. Res. Bd Can. 32: 706-713

Poulet, S. A., Marsot, P. (1978). Chemosensory grazing by marine calanoid copepods (Arthropoda: Crustacea). Science 200: 1403-1405

Poulet, S. A., Marsot, P. (1980). Chemosensory feeding and food-gathering by omnivorous marine coepods. In: Kerfoot, W. C. (ed.) Evolution and ecology of plankton communities. University of New Hampshire, Hanover, p. $198-218$

Price, H. J. (1988). Feeding mechanisms in marine and freshwater zooplankton. Bull. mar. Sci. 43: 327-343

Price, H. J., Paffenhöfer, G.-A. (1984). Effects of experience in the copepod Eucalanus pileatus: a cinematographic study. Mar. Biol. 84: 35-40

Price, H. J., Paffenhöfer, G.-A. (1986). Effects of concentration on the feeding of a marine copepod in algal monocultures and mixtures. J. Plankton Res. 8: 119-128

Price, H. J., Paffenhöfer, G.-A., Strickler, J. R. (1983). Modes of cell capture in calanoid copepods. Limnol. Oceanogr. 28: $116-123$

Raymont, J. E. G. (1983). Plankton and productivity in the oceans, 2nd edn, Vol. 2, Zooplankton. Pergamon, New York

Reeve, M. R., Walter, M. A. (1977). Observations on the existence of lower threshold and upper critical food concentrations for the copepod Acartia tonsa Dana. J. exp. mar. Biol. Ecol. 29: 211-221

Richman, S., Heinle, D. R., Huff, R. (1977). Grazing by adult estuarine calanoid copeods of the Chesapeake Bay. Mar Biol. 42: 69-84

Richman, S., Rogers, J. N. (1969). The feeding of Calanus helgolandicus on synchronously growing populations of the marine diatom Ditylum brightwelli. Limnol. Oceanogr. 14: $701-709$

Roman, M. R. (1977). Feeding of the copepod Acartia tonsa on the diatom Nitzschia closterium and brown algae (Fucus vesciculosus) detritus. Mar. Biol. 42: 149-155

Roman, M. R. (1984). Utilization of detritus by the copepod Acartia tonsa. Limnol. Oceanogr. 29: 949-959

Roman, M. R. (1991). Pathways of carbon incorporation in 
marine copepods: effects of developmental stage and food quality. Limnol. Oceanogr. 36: 796-807

Roman, M. R., Reeve, M. R., Froggert, J. L. (1983). Carbon production and export from Biscayne Bay, Florida. I. Temporal patterns in primary production, seston and zooplankton. Estuar. coast. Shelf Sci. 17: 45-59

Roman, M. R., Rublee, P. A. (1981). A method to measure in situ zooplankton grazing rates on natural particle assemblages. Mar. Biol. 65: 303-309

Rothschild, B. J. (1988). Biodynamics of the sea: the ecology of high dimensionality systems. In: Rothschild, B. J. (ed.) Toward a theory on biological-physical interactions in the world ocean. Kluwer, Boston, p. 527-548

Rothschild, B. J., Osborn, T. R. (1988). Small-scale turbulence and plankton contact rates. J. Plankton Res. 10: 465-474

Ryther, J. H. (1969). Photosynthesis and fish production in the sea. Science 166: 72-76

Schnack, S. B., Elbrächter, M. (1981). On the food of calanoid copepods from the northwest African upwelling region. In: Richards, F. A. (ed.) Coastal upwelling. Am. Geophys. Union, Washington, DC, p. 433-439

Sellner, K., Olson, M. M. (1985). Copepod grazing of red tides in Chesapeake Bay. In: Anderson, D. M., White, A. W., Baden, D. G. (eds.) Toxic dinoflagellates. Proc. 3rd int. Symp., St. Andrews, New Brunswick, Canada. Elsevier, New York, p. 245-250

Sherr, E. B., Sherr, B. F., Paffenhöfer, G.-A. (1986). Phagotrophic protozoa as food for metazoans: a 'missing' link in marine pelagic food webs? Mar. Microb. Fd Webs 1: $60-80$

Smith, P. E., Eppley, R. W. (1982). Primary production and the anchovy population in the Southern California Bight: comparison of time series. Limnol. Oceanogr. 27:1-17

Smith, S. L. (1982). The northwestern Indian Ocean during the monsoons of 1979: distribution, abundance and feeding of zooplankton. Deep Sea Res. 29: 1331-1353

Smith, S. L., Lane, P. V. Z. (1985). Laboratory studies of the marine copepod Centropages typicus: egg production and development rates. Mar. Biol. 85: 153-162

Smith, S. L., Lane, P. V. Z. (1987). On the life history of Centropages typicus: responses to a fall diatom bloom. Mar. Biol. 95: 305-314

Stoecker, D. K., Capuzzo, J. M. (1990). Predation on protozoa: its importance to zooplankton. J. Plankton Res. 12: 891-908

Stoecker, D. K., Egloff, D. A. (1987). Predation by Acartia tonsa Dana on planktonic ciliates and rotifers. J. exp. mar. Biol. Ecol. 110: 53-68

Stoecker, D. K., Sanders, N. K. (1985). Differential grazing by Acartia tonsa on a dinoflagellate and a tintinnid.
J. Plankton Res. 7: 85-100

Støttrup, J. G., Jensen, J. (1990). Influence of algal diet on feeding and egg production of the calanoid copepod Acartia tonsa Dana. J. exp. mar. Biol. Ecol. 141:87-105

Strickler, J. R. (1982). Calanoid copepods, feeding currents and the role of gravity. Science 218: $158-160$

Strickler, J. R., Bal, A. K. (1973). Setae of the first antennae of the copepod Cyclops scutifer (Sars): their structure and importance. Proc. natl Acad. Sci. 70: 2656-2659

Turner, J. T (1984a). The feeding ecology of some zooplankters that are important prey items of larval fish. NOAA Tech. Rep. NMFS 7: 1-28

Turner, J. T. (1984b). Zooplankton feeding ecology: Contents of fecal pellets of the copepods Acartia tonsa and Labidocera aestiva from continental shelf and slope waters near the mouth of the Mississippi River. P.S.Z.N. I Mar. Ecol. 5: 265-282

Turner, J. T. (1984c). Zooplankton feeding ecology: Contents of fecal pellets of the copepods Temora turbinata and $T$. stylifera from continental shelf and slope waters near the mouth of the Mississippi River. Mar. Biol. 82: 73-83

Turner, J. T. (1985). Zooplankton feeding ecology: contents of fecal pellets of the copepod Anomalocera ornata from continental shelf and slope waters of the Gulf of Mexico. P.S.Z.N. I: N.ar. Ecol. 6: 285-298

Turner, J. T. (1987). Zooplankton feeding ecology: contents of fecal pellets of the copepod Centropages velificatus from waters near the mouth of the Mississippi River. Biol. Bull. 173: $377-386$

Turner, J. T., Anderson, D. M. (1983). Zooplankton grazing during dinoflagellate blooms in a Cape Cod embayment, with observations of predation upon tintinnids by copepods. P.S.Z.N. I: Mar. Ecol. 4: 359-374

Tumer, J. T., Tester, P. A., Hettler, W. F. (1985). Zooplankton feeding ecology. A laboratory study of predation on fish eggs and larvae by the copepods Anomalocera ornata and Centropages typicus. Mar. Biol. 90: 1-8

White, J. R, Roman, M. R. (1991), Measurement of zooplankton grazing using particles labelled in light and dark with [methyl ${ }^{3} \mathrm{H}$ ]methylamine hydrochloride. Mar. Ecol. Prog. Ser. $71: 45-52$

White, J. R., Roman, M. R. (1992). Seasonal study of grazing by metazoan zooplankton in the mesohaline Chesapeake Bay. Mar. Ecol. Prog. Ser. 86: 251-261

Wilson, D. S. (1973). Food size selection among copepods. Ecology 54: 909-914

Yen, J. (1988). Directionality and swimming speeds in predator-prey and male-female interactions in Euchaeta rimana, a subtropical marine copepod. Bull. mar. Sci. 43: 395-403

Manuscript first received: January 25, 1993

Revised version accepted: May 25, 1993 